\title{
PERBANDINGAN PERAMALAN PENJUALAN PRODUK AKNIL PT.SUNTHI SEPURIMENGGUANAKAN METODE SINGLE MOVING AVERAGE DAN SINGLE EXPONENTIAL SMOOTING
}

\author{
Nurul Hudaningsih ${ }^{1}$, Silvia Firda Utami ${ }^{2}$, Wari Ammar Abdul Jabbar ${ }^{3}$ \\ 1,2,3) Program Studi Teknik Industri, Fakultas Teknik, Universitas Teknologi Sumbawa \\ nurul.hudaningsih@uts.ac.id ${ }^{1}$, silviafirdautami@gmail.com ${ }^{2}$, wari.ammar@gmail.com ${ }^{3}$
}

\begin{abstract}
ABSTRAC
Forecasting in the company is forecasting product sales to consumers. By knowing product sales can assist the company to provide materials to be produced and determine the production process itself. PT. Sunthi Sepuri is a pharmaceutical company. PT. Sunthi Sepuri often experiences marketing forecasting errors. This causes uncertainty in the amount of production so that it can cause employee productivity to decrease due to the increasing amount of production at any time. In this study demand forecasting will be held at PT. Sunthi Sepuri. This research apply the Single Moving Average and Single Exponential Smoothing methods, with the sample to be used is Aknil product, this product is a pain-relieving drug. Use the two methods to compare the most accurate forecasting methods and close to the actual value. The research methods start from gathering historical data, determining forecasting methods, forecasting calculations, determining the best method, and withdrawing conclusions. Based on the test results that the method that can be used to analyze data that has a small error rate is the Single Moving Average method. Forecasting results for July 2019 with the Single Exponential Smoothing method using $\alpha: 0.8$ are 408,488 caplets. As for July 2019, the Single Moving Average method is 466.
\end{abstract}

Keyword: Sales Forecasting, Single Moving Average, Single Exponential smooting.

\begin{abstract}
ABSTRAK
Salah satu peramalan yang dilakukan oleh perusahaan adalah peramalan penjualan produk kepada konsumen. Dengan mengetahui penjualan produk, dapat membantu perusahaan untuk menyediakan material yang akan di produksi dan menentukan proses produksi itu sendiri. PT.Sunthi Sepuri adalah perusahaan Pharmaceutical manufacture atau perusahaan yang bergerak di pembuatan obat-obatan. PT.Sunthi Sepuri sering mengalami kesalahan peramalan dari pihak marketing. Hal ini menyebabkan ketidak pastian jumlah produksi sehingga dapat menyebabkan produktifitas karyawan menurun karena meningkatnya jumlah produksi sewaktu-waktu. Pada penelitian ini peramalan permintaan akan diadakan pada PT.sunthi Sepuri dengan menerapkan metode Single Moving Average dan Single Exponential Smoothing, dengan sampel yang akan digunakan adalah produk Aknil produk ini adalah obat penahan rasa nyeri. Penggunaan kedua metode tersebut untuk membandingkan kedua metode peramalan tersebut untuk membandingkan metode peramalan yang paling akurat dan mendekati nilai aktual. Metode penelitian yang digunakan mulai dari pengumpuan data historis, penentuan metode peramalan, perhitungan peramalan, penenuan metode terbaik, dan penariakan kesimpulan. Berdasarkan hasil pengujian bahwa metode yang dapat digunakan untuk menganalisis data yang memiliki tingkat kesalahan paing kecil adalah metode Single Moving Average. Hasil peramalan untuk bulan juli 2019 dengan metode Single Exponential Smoothing menggunakan $\alpha$ : 0,8adalah 408.488 kaplet. Sedangkan untuk pemalan bulan juli 2019 dengan metode Single Moving Averageadalah 466.
\end{abstract}

Kata Kunci : Peramalan Penjualan, Single Moving Average, Single Exponential smooting. 


\section{Pendahuluan}

PT.Sunthi Sepuri adalah salah satu perusahaan Pharmaceutical manufacturetatau salah satu manufaktur produksi farmasi.PT. Sunthi Sepuri memiliki pabrik yang terletak di kecamatan Cikupa, Kabupaten Tangerang, Provinsi Banten. PT. Sunthi Sepuri menghasilkan obat-obat guna membangun bangsa yang sehat dan sejahtera.

Dalam kegiatan pemasaran perusahaan menggunakan tenaga kerja yang disebut Medical Representative. Ratih dan Imron (2017:02) menyatakan Medical Representative adalah orang yang bertugas untuk mengenalkan dan menawarkan produk kepada dokter.Medical Representative memberkan hasil mereka kepada pihak pemasaran dan pihak pemasaran membuat peramalan yang diberikan kepada pihak Production Planning and Inventory Management (PPIC).

Pihak PPIC menerima peramalan kemungkinan produk yang akan di beli, namun, sering terjadinya kesalahan perhitungan peramalan dari pihak pemasaran yang mengakibatkan bagian produksi lelah karena permintaan yang tinggi tiba-tiba. Oleh karena itu harus dilakukannya peninjauan terhadap peramalan untuk penjualan untuk mengoptimalkan produktifitas karyawan.

Sebelum membuat peramalan dibutuhkannya sample produk yang ingin diramalkan penjualan. Maka dari itu diambilkan sample produk yaitu Aknil obat penahan rasa nyeri. Obat ini dipilih karena memiliki penjualan yang tinggi dan dapat menambah keuntungan lebih besar bila lebih optimal penjualannya.

Untuk menentukan peramalan perlu di lihat data statistik dari produk yang akan di teliti, maka dari itu dilakukannya wawancara dan menghasilkan data statistik sebagai berikut:

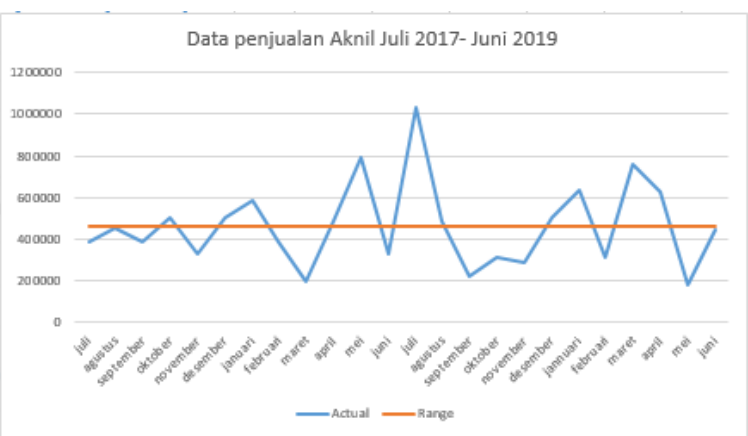

Gambar 1. Statistik penjualan produk Aknil periode juli 2017 - juni 2019
Dari data di atas dapat dilihat bahwa data memiliki pola Horizon atau Stasioner. Menurut Sri Ajeng (2017:12) pola data Horizontal adalah pola data yang berfluktuasi disekitar nilai rata-rata. Suatu produk yang penjualannya tidak meningkat atau menurun selama waktu tertentu termasuk jenis pola ini termasuk pola jenis ini juga.Teknik yang sering digunakan untuk peramalan adalah rata-rata bergerak dan pemulusan eksponensial, dari hal tersebut penulis ingin melakukan pemerataan perbulannya. Oleh karena itu penulis akan melakukan peramalan dengan metode rata-rata bergerak tunggal (SingleMoving Average) dan metode penghalusan eksponential (Single Exponential Smoothing), lalu membandingkan kedua metode hingga menemukan peramalan yang paling tepat untuk digunakan.

Berdasarkan permasalahan diatas maka dapat di uraikan permasalahan sebagai berikut :(1) Bagaimana hasil peramalan penjualan dan error dari perhitungan produk Aknil dengan menggunakan metode SingleMoving Average dan Single Exponential Smoothing ? (2) Metode mana yang paling optimal digunakan untuk peramalan penjualan produk Aknil diantara metode SingleMoving Average dan Single Exponential Smoothing?

Adapun tujuan dari penelitian ini yaitu: (1) Mengetahui hasil peramalan dan error dari perhitungan produk Aknil dengan menggunakan metode SingleMoving Average dan Single Exponential Smoothing (2) Mengetahui peramalan penjualan mana lebih optimal dengan menggunakan metode SingleMoving Average atau Single Exponential Smoothing untuk produk Aknil.

\section{Tinjauan Pustaka \\ Peramalan}

Peramalan adalah pemikiran terhadap suatu besaran, misalnya permintaan terhadap suatu produk atau beberapa produk pada periode yang akan datang yang akan datang. Ada hakekatnya peramalan hanyalah suatu pemikiran (guess), tapi dengan menggunakan teknik-teknik tertentu peramalan mejadi lebih dari sekedar perkiraan. Peramalan dapat dikatakan perkiraan yang ilmiah (educated guess). Setiap pengambila keputusan yang akan datang, maka pasti ada peramalan yang melandasi pengambilan keputusan tersebuttersebut (Rosnani Giting di tulis dalam jurnal Mukti Qamal 2015: 26).

Jika dilihat dari jangka waktu ramalan yang telah disusun, maka ramalan dapat dibedakan menjadi 3 (Murahartawaty, 2009), yaitu:

a. Short term forecasting (peramalan jangka pendek), yaitu peramalan yang dilakukan untuk 
menyusun peramalan yang jangka waktunya harian, hingga setiap jam.

b. Mid term forecasting (peramalan jangka menengah), yaitu peramalan yang dilakukan untuk menyusun peramalan yang jangka waktunya mingguan hingga bulanan.

c. Long term forecasting (peramalan jangka panjang), yaitu peramalan yang dilakukan untuk menyusun peramalan yang jangka waktunya bulanan hingga tahunan.

\section{Metode Single Moving Average}

Single Moving Average adalah salah satu metode peramalan Time series (deret waktu). Metode ini digunakan jika data masa lalu tidak memiliki unsur trend atau faktor musiman (Alfian dan Sri, 2107:20).

Tujuan dilakukannya peramalan rata-rata bergerak tunggal adalah untuk menghilangkan atau mengurangi acakan (random ness) dalam deret waktu. Tujuan ini dapat dicapai dengan merataratakan beberapa nilai dalam data bersama-sama, dengan cara mana kesalahan positif dan negatif yang mungkin terjadi dan dapat dikeluarkan atau dihilangkan Assauri (dalam Alfian dan Sri, 2107:20).

Single Moving Average adalah suatu metode peramalan yang dilakukan dengan mengambil sekelompok nilai pengamatan, mencari nilai rata-rata tersebut sebagai ramalan untuk periode yang akan datang.

Metode ini mempunyai karateristik khusus yaitu :

a. Untuk mendapatkan atau menentukan ramalan pada periode yang akan datang memerlukan data historis selama jangka waktu tertentu, misalnya dengan 3 bulan moving average, maka ramalan bulan 5 baru bisa dibuat setelah bulan ke 4 selesai atau berakhir.

b. Semakin panjang jangka waktu single moving average, efek pelicinan semakin terlihat dalam ramalan atau menghasilkan singlemoving average yang semakin halus.

Persamaan matematis single moving average :

$$
F_{t+1} \frac{A_{t}+A_{t-1} \cdots+A_{t-n+1}}{N}
$$

Dimana :

At = data pengamatan periode $\mathrm{t}$

$\mathrm{N}=$ Jumlah deret waktu yang digunakan

$\mathrm{Ft}+1=$ nilai peramalan periode $\mathrm{t}+1$

$\mathrm{n} \quad=$ Periode yang digunakan

\section{Metode Single Exponential Smooting}

Metode Exponential Smooting adalah suatu prosedur yang mengulang penghutingan secara terus menerus yang menggunakan data terbaru. Setiap data diberikan bobot yang di simbolkan dengan $\alpha$. Simbol $\alpha$ bisa ditentukan secara bebas yang dapat mengurang beban forecast error. Nilai konstanta pemulusan dapat ditentukan dengan ketentuan $0<\alpha<1$ (dalam Ni dan Igp, 2014:100).

Pada ketentuanya nilai-nilai $\alpha$ rendah akan menyebabkan jarak yang lebih rendah dari trend. Nilai $\alpha$ yang rendah cocok digunakan bila data bersifat stabil. Nilai-nilai $\alpha$ yang lebih tinggi digunakan ketika data bersifat resposif atau mempunyai fluktuasi permintaan yang tinggi. Mencari nilai $\alpha$ yang tepat dapat ditentukan dengan pengujian trial dan error (coba-coba) terhadap nilai $\alpha$ yang berbeda untuk menentukan nilai $\alpha$ yang memiliki hasil dengan nilai error terkecil (Sri,2014: $15)$.

Rumus untuk Single Exponentiala Smooting adalah sebagai berikut:

$\mathrm{F}_{t}=\mathrm{F}_{t-1}+\alpha\left(A_{t-1}-\mathrm{F}_{t-1}\right)$

Dimana:

$\mathrm{F}_{\mathrm{t}} \quad=$ Nilai peramalan periode $\mathrm{t}$

$\mathrm{F}_{\mathrm{t}-1}=$ Perkiraan peramalan periode sebelumnya

$\alpha \quad=$ Konstata Eksponensial

$\mathrm{A}_{\mathrm{t}-1} \quad=$ Data Pengamatan Periode $\mathrm{t}-1$

Menurut Render dan Heizer (2001 : 54) permsalahan yang sering dihadapi dalam masalah ini adalah bagaimana menentukan nilai $\alpha$ yang tepat untuk meminimkan kesalahan peramalan . Karena berlaku 0 $<\alpha<1$ maka dapat melakukan panduan berikut:

a. Apabila Pola historis data sangat bergejolak atau tidak stabil maka pilih nilai $\alpha$ mendekati satu.

b. Apabila pola historis data tidak bergejolak dan mendekati stabil maka pilih nilai $\alpha$ mendekati nilai nol.

\section{Pengukuran Akurasi Hasil Peramalan}

Ukuran akurasi hasil peramalan yang merupakan ukuran kesalahan peramalan merupakan ukuran tentang tingkat perbedaan antara hasil permintaan dengan permintaan yang sebenarnya terjadi. Beberapa metode telah digunakan untuk menunjukkan kesalahan yang disebabkan oleh suatu teknik peramalan tertentu.Hampir semua ukuran tersebut menggunakan pengrata-rataan beberapa fungsi dari perbedaan antara nilai sebenarnya dengan nilai peramalannya. Diantaranya adalah sebagai berikut :

a. Mean Absolute Deviation (MAD)

MAD merupakan rata-rata kesalahan mutlak selama periode tertentu tanpa memperhatikan apakah hasil peramalan lebih besar atau lebih kecil dibandingkan kenyataannya. Secara 
metematis, MAD dirumuskan sebagai berikut (Nasution dan Prasetyawan, 2008 : 34):

$M A D\left|\frac{A t-F t}{n}\right|=$

Dimana :

At $=$ permintaan actual pada priode ke $t$

$\mathrm{Ft}=$ peramalan permintaan pada priode ke $\mathrm{t}$

$\mathrm{N}$ = jumlah priode peramalan yang terlibat

\section{b. Mean Square Error $=(\mathrm{MSE})$}

MSE merupakan metode alternatif dalam suatu metode peramalan. Pendekatan ini penting karena teknik ini menghasilkan kesalahan yang moderat lebih di sukai oleh suatu peramalan yang menghasilkan kesalahan yang sangat besar.Rumus Mean Square Error (Nasution dan Prasetyawan, 2008 : 34):

$M S E=\frac{\sum{\text { (Kesalahan permalana })^{2}}_{N}}{N}$.

c. Mean Absolute PercentageError (MAPE)

MAPE merupakan ukuran kesalahan relativ. MAPE biasanya lebih berarti dibandingakan MAD karena MAPE menyatakan persentase kesalahan hasil peramalan terhadap permintaan aktual selama periode tertentu yang akan memberikan informasi persentase kesalahan terlalu tinggi atau terlalu rendah. Secara matematis, MAPE dinyatakan sebagai berikut (Nasution dan Prasetyawan, 2008 :35): MAPE $\frac{\sum \text { (Deviasi Absolut)/(Nilai Actual)X } 100 \%}{N}$.(5)

Untuk membantu perhitungan error peneliti menghitung nilai forcasting error (Fe) dan nilai Percentil Error (Pe) agar lebih mudah untuk mencari hasil dari error tersebut.

$F e=A t-F t$

Dimana :

At $\quad=$ Actual

$\mathrm{Ft}=$ Hasil Peramalan pada periode ke-t

$P e=\frac{|F e|}{A t}$.

Dimana :

$\mathrm{Fe} \quad=$ Kesalahan peramalan

At $\quad=$ Actual

\section{Software QSB}

Software QSB (Quantity System for business) atau umumnya juga dikenal dengan nama WINQSB (QSB yang berjalan pada sistem operasi Windows) merupakan software yang mengandung algoritma problem solving untuk riset operasi (operational research) dan untuk ilmu manajemen. Didalam WINQSB sendiri terdapat beberapa modul yang digunakan untuk menyelsaikan masalah operation riset dan ilmu manajmen seperti analisis sampling, goal programing, tata letak fasilitas, peramalan permintaan dan lain sebagainya.

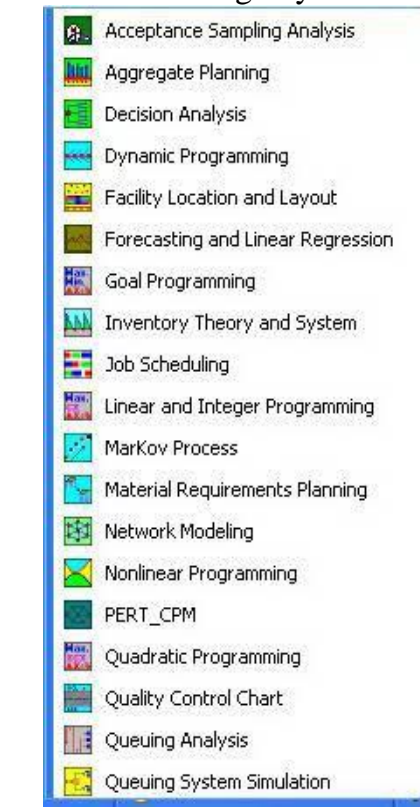

Gambar2. Sub menu pada WINQSB

WinQSB dapat melakukan peramalan menggunakan menu Forecasting and Linier Regression. Peramalan menggunakan data-data sebelumnya, sehingga dapat memprediksi data diwaktu yang akan datang. Dengan program WinQSB ini dapat mengenali data untuk peramalan time series dan regretion forecasting.

\section{Metode Penelitian}

Metode yang digunakan dalam penelitian ini adalah metode kuantitatif. Metode peramalan kuantitatif yaitu suatu cara yang digunakan untuk menjawab masalah penelitian yang berkaitan dengan angka dan program statistik. Metode Single Moving Averagedan Single Eponential Smooting merupakan metode time series. Metode time series adalah peramalan berdasarkan perilaku data masa lampau dengan untuk diproyeksikan ke masa depan dengan memanfaatkan persamaan matematika dan statistik.

Alur penelitian dimulai dengan pencarian literatur untuk penyelesaian masalah dan di akhiri dengan pemberian kesimpulan dan saran, untuk lebih jelasnya akan disampaikan melalui flowchart berikut: 


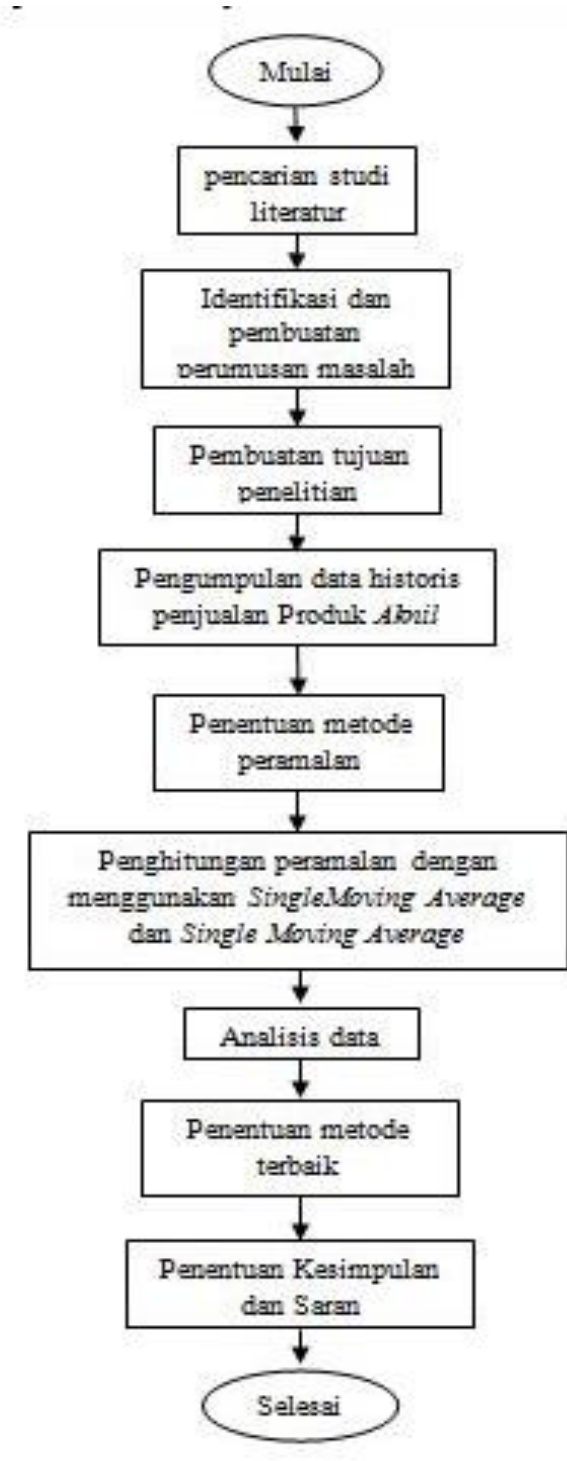

Gambar 3.1. Flowchart Penelitian Sumber: Penelitian

\section{Hasil Dan Pembahasan}

Pengambilan data di lakukan di departemen PPIC PT. Sunthi Sepuri. Pada penelitian ini data yang di ambil untuk diolah adalah data penjualan produk Aknil pada bulan Juli 2018 sampai Juni 2019. Dalam data ini terdapat periode dan jumlah penjualan produk Aknil. Data tersebut dapat dilihat pada tabel 1sebagai berikut:

Tabel 1.Data penjualan produk Aknil Bulan juli 2018 sampai juni 2019

\begin{tabular}{|l|l|c|r|}
\hline NO & BULAN & TAHUN & PENJUALAN \\
\hline 1 & Juli & 2018 & 1.029 .100 \\
\hline 2 & Agustus & 2018 & 489.200 \\
\hline 3 & September & 2018 & 219.800 \\
\hline 4 & Oktober & 2018 & 315.300 \\
\hline 5 & November & 2018 & 287.500 \\
\hline 6 & Desember & 2018 & 505.400 \\
\hline 7 & Jannuari & 2019 & 638.500 \\
\hline 8 & Februari & 2019 & 314.000 \\
\hline 9 & Maret & 2019 & 758.500 \\
\hline 10 & April & 2019 & 631.200 \\
\hline 11 & Mei & 2019 & 184.000 \\
\hline 12 & Juni & 2019 & 443.000 \\
\hline RATA-RATA & & $\mathbf{4 8 4 . 6 2 5}$ \\
\hline TOTAL & & $\mathbf{5 . 8 1 5 . 5 0 0}$ \\
\hline
\end{tabular}

Data yang telah di dapatkan kemudian dibuat dua perhitung manual dengan membagi 5 periode untuk metode Single Moving Average dan dengan nilai $\alpha$ sebesar 0,8 untuk metode Single Exponential Smooting. Setelah dihitung manual lalu dihitung kembali menggunakan software WINQSB.

\section{Perhitungan Single Moving Smooting}

Hasil perhitungan dengan metode Single Moving Smooting menggunakan rumus (1) dengan perhitungan errorMean Absuute Deviation (MAD), Mean Square Error(MSE) danMean Absolute PercentageError(MAPE) menggunakan rumus (3), (4), dan (5) menghasilkan hasi perhitungan sebagai tabel berikut:

Tabel 2. Hasil Peramalan Penjualan Aknil menggunakan metode Single Moving Averagae

\begin{tabular}{|l|r|r|r|r|r|r|r|r|r|r|}
\hline $\mathbf{n}$ & \multicolumn{1}{l}{ At } & $\mathbf{F t}$ & $\mathbf{F e}$ & $\mathbf{F e} \mid$ & $\mathbf{F} \mathbf{F}^{2}$ & $\mathbf{P e}$ & $|\mathbf{P e}|$ & $\mathbf{M A D}$ & MSE & MAPE \\
\hline 1 & 1.029 .100 & - & - & - & - & - & - & - & - & - \\
\hline 2 & 489.200 & - & - & - & - & - & - & - & - & - \\
\hline 3 & 219.800 & - & - & - & - & - & - & - & - & - \\
\hline 4 & 315.300 & - & - & - & - & - & - & - & - & - \\
\hline 5 & 287.500 & - & - & - & - & - & - & - & - & - \\
\hline 6 & 505.400 & 468.180 & 37.220 & 37.220 & 1.385 .328 .400 & 0,074 & 0,074 & $37.220,00$ & 1.385 .328 .400 & $7,36 \%$ \\
\hline 7 & 638.500 & 363.440 & 275.060 & 275.060 & 75.658 .003 .600 & 0,431 & 0,431 & $156.140,00$ & 38.521 .666 .000 & $25,22 \%$ \\
\hline 8 & 314.000 & 393.300 & -79.300 & 79.300 & 6.288 .490 .000 & 0,253 & 0,253 & $130.526,67$ & 20.832 .955 .500 & $25,23 \%$ \\
\hline 9 & 758.500 & 412.140 & 346.360 & 346.360 & 119.965 .249 .600 & 0,457 & 0,457 & $184.485,00$ & 50.824 .267 .900 & $30,34 \%$ \\
\hline 10 & 631.200 & 500.780 & 130.420 & 130.420 & 17.009 .376 .400 & 0,207 & 0,207 & $173.672,00$ & 44.061 .289 .600 & $28,40 \%$ \\
\hline 11 & 184.000 & 569.520 & -385.520 & 385.520 & 148.625 .670 .400 & 2,095 & 2,095 & $208.980,00$ & 61.488 .686 .400 & $58,59 \%$ \\
\hline 12 & 443.000 & 505.240 & -62.240 & 62.240 & 3.873 .817 .600 & 0,14 & 0,14 & $188.017,14$ & 53.257 .990 .857 & $52,23 \%$ \\
\hline 13 & - & 466.140 & - & - & & - & - & - & - & - \\
\hline
\end{tabular}


Hasil untuk peramalan jumlah penjualan bulan yang akan datang adalah 466.140 kaplet setiap bulannya. Hasil ini dapat dilihat dari tabel pada Ft bulan ke 13 . Adapun hasil lain yang tertera pada tabel 4.2 adalah jumlah error yang terdapat pada kolom 12 yaitu 188.017,14(MAD), 53.257.990.857 (MSE), 52,23\% (MAPE).

Peramalan menggunakan metode Single Moving Average menggunakan software WinQSB dengan cara menginput data penjualan barang yang tercantum pada tabel 1 kedalam sistem WinQSB. Maka hasil peramalan bulan berikutnya dapat dilihat dari peramalan bulan ke 13 di dalam gambar tabel hasil WINQSB berikut:

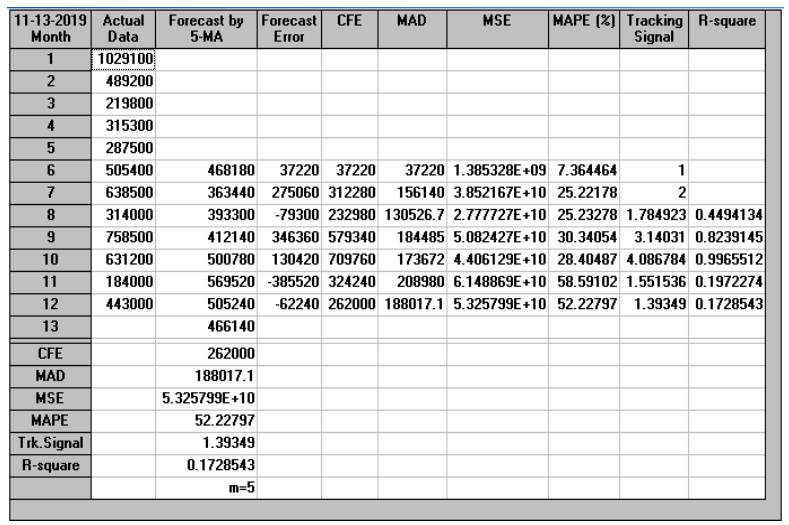

Gambar 3.Hasil perhitungan SingleMoving Average di WINQSB

Pada gambar 3 dapat dilihat hasil peramalan bulan ke 13 pada kolom 13 dengan jumlah 466.140. Gambar diatas juga menyebutkan hasil error yang didapatkan adalah 188.017,1 (MAD), 5,325799E+10 (MSE) dan $52,22797 \%$ (MAPE).
Jika dilihat pada hasil perhitungan manual dan bibandingkan dengan hasil dari perhitungan software WINQSB, Jumlah peramalan metode SingleMoving Average dan errornya sama yaitu dengan hasil 466.140 pada periode selanjutnya dan dengan error 188.017,14(MAD), 53.257.990.857 (MSE), 52,23\% (MAPE). Dari data tersebut dapat disimpulkan bahwa perhitungan manual dan rumus yang digunakan sudah benar.

\section{Perhitungan Single Exponential Smooting}

Hasil perhitungan dengan metode Single Exponential Smooting menggunakan rumus (2) dengan perhitungan errorMean Absuute Deviation (MAD), Mean Square Error(MSE) dan Mean Absolute PercentageError (MAPE) menggunakan rumus (3), (4), dan (5) menghasilkan hasi perhitungan sebagai tabel 3.

Hasil untuk peramalan jumlah penjualan bulan bulan yang akan datang adalah 409.487,8 kaplet setiap bulannya. Hasil ini dapat dilihat dari tabel pada $\mathrm{Ft}$ bulan ke 13. Adapun hasil lain yang tertera pada tabel 4.2 adalah jumlah error yang terdapat pada kolom 12 yaitu 245.516,5349 (MAD), 89.453.961.519 (MSE), $73,07 \%$ (MAPE).

Peramalan menggunakan metode Singel Exponential Smooting menggunakan software WinQSB dengan cara menginput data barang keluar yang tercantum pada tabel 1 kedalam sistem WinQSB. Maka hasil peramalan bulan berikutnya dapat dilihat dari peramalan bulan ke 13 di dalam gambar 4 .

Tabel 3. Hasil Peramalan Penjualan Aknil menggunakan metode Single Exponential Averagae

\begin{tabular}{|c|c|c|c|c|c|c|c|c|c|c|}
\hline No & At & $\mathbf{F t}$ & $\mathbf{F e}$ & {$[\mathrm{Fe}]$} & $\mathrm{Fe}^{\wedge} 2$ & $\mathbf{P e}$ & {$[\mathrm{Pe}]$} & MAD & MSE & MAPE \\
\hline & 1.029 .100 & & & & & & & & & \\
\hline & 489.200 & 1.029 .100 & -539.900 & 539.900 & 291.492 .010 .000 & 1,103 & 1,103 & 539.900 & 291.492 .010 .000 & $110,36 \%$ \\
\hline & 219.800 & 597.180 & -377.380 & 377.380 & 142.415 .664 .400 & 1,716 & 1,716 & 458.640 & 216.953 .837 .200 & $141,03 \%$ \\
\hline 4 & 315.300 & 295.276 & 200.24 .00 & 20.024 & 400.960 .576 & 0,063 & 0,063 & $312.434,67$ & 144.769 .544 .992 & $96,14 \%$ \\
\hline 5 & 287.500 & $311.295,20$ & $23.795,20$ & $23.795,20$ & 566.211 .543 & 0,082 & 0,082 & $240.274,80$ & 108.718 .711 .630 & $74,17 \%$ \\
\hline 6 & 505.400 & 292.259 & 213.141 & 213.141 & 45.429 .068 .830 & 0,421 & 0,421 & $234.848,03$ & 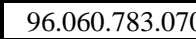 & $67,77 \%$ \\
\hline 7 & 638.500 & $462.771,80$ & $175.728,20$ & $175.728,20$ & 30.880 .397 .464 & 0,275 & 0,275 & $224.994,73$ & 85.197 .385 .46 & $61,06 \%$ \\
\hline 8 & 314.000 & \begin{tabular}{|l|}
$603.354,40$ \\
\end{tabular} & \begin{tabular}{|r|}
-289.354 \\
\end{tabular} & $289.354,40$ & 83.725 .946 .577 & 0,921 & 0,921 & \begin{tabular}{|l|}
$234.188,96$ \\
\end{tabular} & 84.987.179.913 & $65,50 \%$ \\
\hline 9 & 758.500 & $371.870,90$ & \begin{tabular}{|l|}
$386.629,10$ \\
\end{tabular} & $386.629,10$ & 149.482 .082 .371 & 0,509 & 0,509 & $253.243,98$ & $93.049 .042 .72 \mathrm{C}$ & $63,69 \%$ \\
\hline 10 & 631.200 & $681.174,20$ & $-49.974,20$ & $49.974,17$ & 2.497 .418 .113 & 0,079 & 0,079 & $230.658,45$ & 82.987 .751 .097 & $57,49 \%$ \\
\hline 11 & 184.000 & $641.194,80$ & -457.195 & $457.194,80$ & 209.027 .117 .053 & 2,484 & 2,484 & $253.312,09$ & 95.591 .687 .69 & $76,59 \%$ \\
\hline 12 & 443.000 & 275.439 & 167.561 & 167.561 & 28.076 .699 .787 & 0,378 & 0,378 & $245.516,53$ & $89.453 .961 .51 \mathrm{c}$ & $73,07 \%$ \\
\hline 13 & & $409.487,80$ & & & & & & & & \\
\hline
\end{tabular}




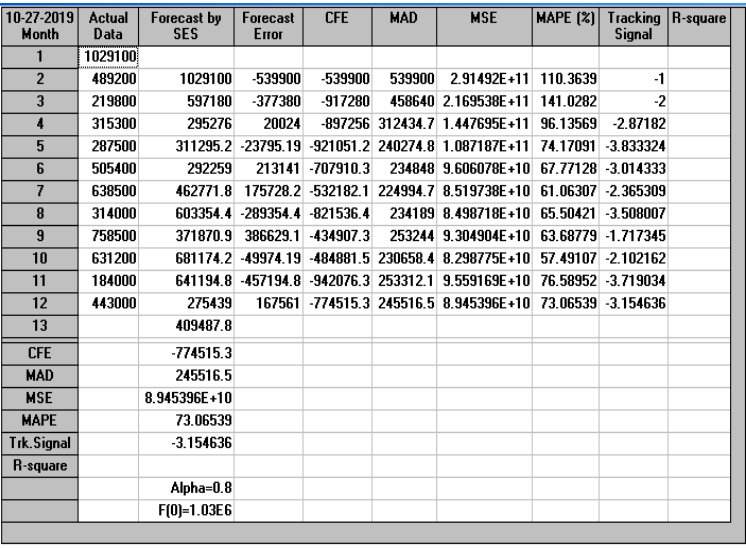

Gambar 4. Hasil perhitungan Single Exponential Smooting di WINQSB

Jika dilihat pada hasil perhitungan manual dan bibandingkan dengan hasil dari perhitungan software WINQSB, Jumlah peramalan metode SingleExponential Smooting dan errornya sama yaitu dengan hasil 409.487,8 pada periode selanjutnya dan dengan error 245.516,5349 (MAD), 89.453.961.519 (MSE), 73,07\% (MAPE). Dari data tersebut dapat disimpulkan bahwa perhitungan manual dan rumus yang digunakan sudah benar.

\section{Hasil Peramalan}

Hasil Peramalan jumlah penjualan produk aknil dengan metode Single Moving Average dan Singel Exponential Smooting periode (bulan) selanjutnya. Data yang diambil adalah data produk yang keluar dari PT.Sunthi Sepuri. Jumlah data terhitung, yaitu 12 bulan dari Juli 2018 sampai Juni 2019. Namun data yang di analisis untuk menentukan metode paling tepat adalah data dari tabel 4.2 untuk Single Moving Average dan tabel 4.3 untuk Singel Exponential Smooting masing-masing data di ambil dari bulan ke 12 data yang diambil adalah sebagai berikut:

Tabel 4 Hasil peramalan

\begin{tabular}{|l|c|c|c|c|}
\hline Peramalan & Ft & MAD & MSE & MAPE \\
\hline SMA & 505.240 & $188.017,14$ & 5.327 .990 .857 & $52,53 \%$ \\
\hline SES & 274.439 & $245.516,54$ & 89.453 .961 .519 & $73,07 \%$ \\
\hline
\end{tabular}

Tabel 4 merupakan hasil perhitungan peramalan jumlah produk aknil menggunakan metode Single Moving Average dan Singel Exponential Smooting Bulan ke 12. Dengan pengukuran menggunakan MAD, MSE dan MAPE. Didapatkan hasil peramalan untuk periode selanjutnya pada tabel $(\mathrm{Ft})$ untuk bulan berikutnya. Dilihat dari diagram MAD, MSE dan MAPE sebagai berikut:
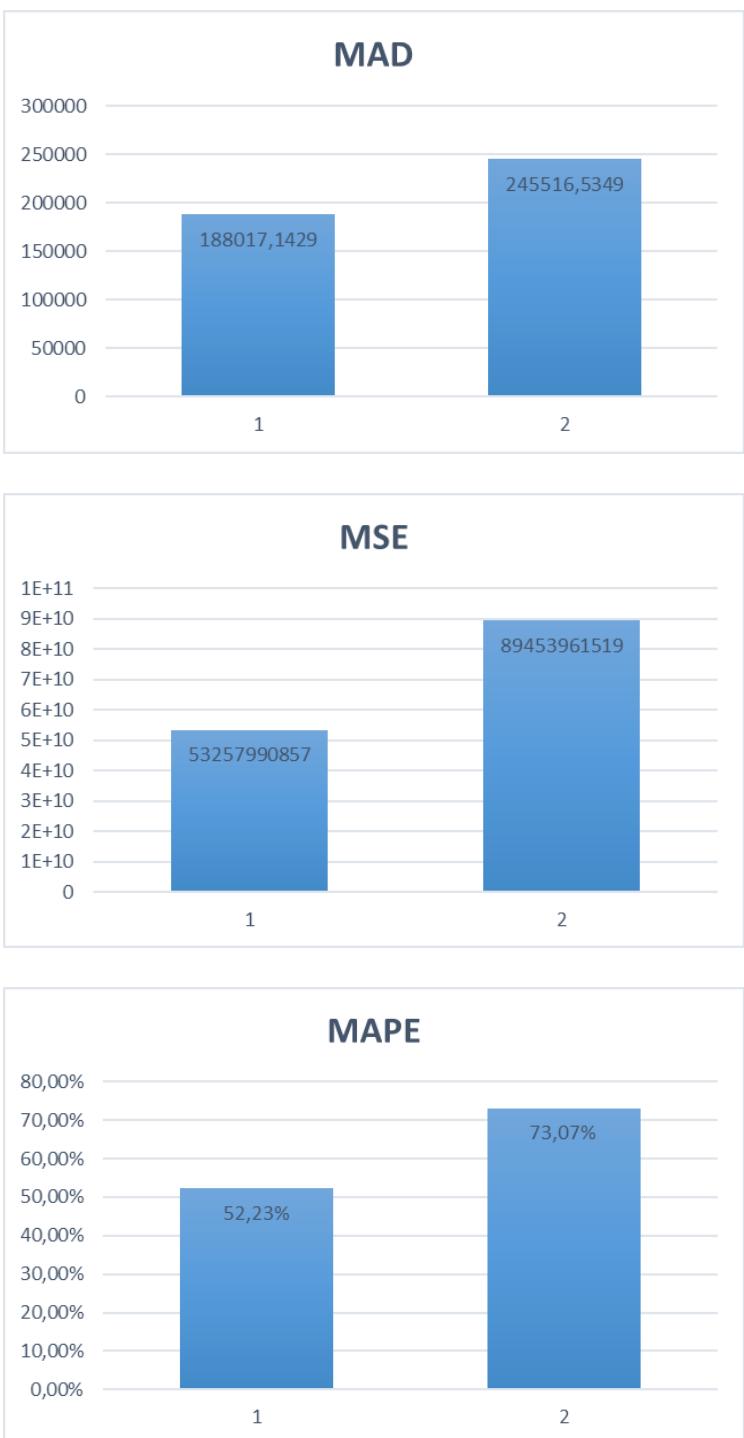

Gambar 5. Diagram MAD, MSE, dan MAPE perbandingan Metode Single Moving Average dan Single Exponential Smooting

Pada gambar 4.5 di mana nomor 1 adalah Metode Single Moving Average sedangkan nomor 2 Metode Single Exponential Smooting. Diperlihatkan jumlah error dari dari masing-masing metode adalah 188.017,14(MAD), 53.257.990.857 (MSE), 52,23\% (MAPE) dan 245.516,5349 (MAD), 89.453.961.519 (MSE), 73,07\% (MAPE). Error terhitung besar di karenakan Data yang diolah termasuk data yang siklus yang terdapat renggang penjualan antar bulan lebih dari 50\%. Namun, tidak menjadi masalah karena peneliti berniat untuk merata-ratakan jumlah produksi.

Dalam penelitian ini penulis mencari nilai error terkecil. Dalam gambar 4.5 nomor 1 (Single Moving 
Average) memiliki error terkecil yaitu 188.017,14(MAD), 53.257.990.857 (MSE), 52,23\%

(MAPE) sehingga peramalan Single Moving Average sebagai metode peramalan yang lebih baik dari pada metode Single Exponential Smooting dan lebih cocok digunakan untuk produk Aknil di PT.Sunthi Sepuri ini.

\section{Kesimpulan Dan Saran}

Setelah dilakukan pengumpulan serta pengolahan data maka dapat disimpulkan Sebagai berikut:

a. Peramalan penjualan produk Aknil dengan metode Singel Moving average menghasilkan peramalan 466.140 kaplet dengan error sebesar 188017,14 (MAD), 5327990857 (MSE), 52,53\% (MAPE) dan metode Single Exponential Smooting menghasilkan peramalan 409.488 kaplet dengan error sebesar245516,54 (MAD),89453961519 (MSE), 73,07\% (MAPE).

b. Peramalan penjualan Produk Aknil di PT.Sunthi Sepuri dengan menggunakan metode Single Moving Average lebih tepat digunakan dan lebih optimal dibandingkan dengan metode Single Exponentia Smooting Karena metode Single Moving Average memiliki error yang lebih kecil.

Dari hasil penelitian penulis mendapatkan saranuntuk mengguanakan data terbaru sehingga pengambilan keputusan lebih tepat dan menghasilkan perhitungan yang lebih pasti.

\section{Referensi}

[1] Ajeng, Sri,"Peramalan Penjualan untuk Perencanaan Pengadaan Persediaan Buah Durian di Rumah Durian Harum Bintaro Jakarta”. Universitas Islam Negeri Jakarta: Jakarta, 2011.

[2] Muhrahmawati, "Peramalan", Sekolah Tinggi Teknologi Telkom: Bandung, 2009.

[3] Nasution, A. H. dan Prasetyawan, "Perencanaan dan pengendalian Produksi”, Edisi pertama. Graha ilmu:Yogyakarta,2008.

[4] Nurlifa A. Dan Kusumadewi S., "Sistem Peramalan Jumlah Penjualan Menggunakan Metode Moving Average Pada Rumah Jilbab Zaky”, Jurnal Inovtek Polbeng - Seri Informatika, Vol. 2, No. 1, hlm. 20. e-ISSN : 2527-9866, 2017

[5] Purwanto A. dan Hanief S.,"Teknik Peramalan dengan Doble Exponential Smoothing Pada Distributor Gula",Jurnal
Teknologi Informasi dan Komputer, Vol. 3, No. 1, Hlm.364-367,2017.

[6] Qamal M.“Peramalan Penjualan Makanan Ringan dengan Metode Single Exponential Smooting”, Techsi : Jurnal Penelitian Teknik Informatika, Hlm. 26,2015.

[7] Riyadi S. "Aplikasi Peramalan Penjualan Obat Menggunakan Metode Pemulusan (Studi Kasus: Instalasi Farmasi RSUD Murjani)”, Seminar Nasional Teknologi Informasi dan Multimedia, hlm. 536,2015.

[9] WulandariR. DanImron A.,"Modal Sosial Medical Representative Perusahaan farmasi di Kota Madiun”,Paradigma, Vol. 05,No. 03,2017.

[10] Yuniastari N.L.danWirawan I. W.,"Peramalan Permintaan Produk Perak Menggunakan Metode Simple Moving Average Dan Exponential Smoothing, ${ }_{2}$ Jurnal Sistem dan Informatika, Vol. 09 No. 01, hlm. 100,2014 . 